\title{
Changes in black carbon deposition to Antarctica from two high-resolution ice core records, 1850-2000 AD
}

\author{
M. M. Bisiaux ${ }^{1}$, R. Edwards ${ }^{1,2}$, J. R. McConnell ${ }^{1}$, M. A. J. Curran ${ }^{3,4}$, T. D. Van Ommen ${ }^{3,4}$, A. M. Smith ${ }^{5}$, \\ T. A. Neumann ${ }^{6}$, D. R. Pasteris ${ }^{1}$, J. E. Penner ${ }^{7}$, and K. Taylor ${ }^{1}$ \\ ${ }^{1}$ Desert Research Institute, Reno, NV, USA \\ ${ }^{2}$ Curtin University, Perth, WA, Australia \\ ${ }^{3}$ Australian Antarctic Division, Kingston, TAS, Australia \\ ${ }^{4}$ Antarctic Climate and Environment CRC, University of Tasmania, Hobart, TAS, Australia \\ ${ }^{5}$ Australian Nuclear Science and Technology Organisation, Lucas Heights, NSW, Australia \\ ${ }^{6}$ Goddard Space Flight Center, NASA, Greenbelt, MD, USA \\ ${ }^{7}$ University Michigan, Ann Arbor, MI, USA
}

Correspondence to: M. M. Bisiaux (marion.ma.bisiaux@gmail.com)

Received: 6 September 2011 - Published in Atmos. Chem. Phys. Discuss.: 12 October 2011

Revised: 8 March 2012 - Accepted: 24 April 2012 - Published: 9 May 2012

\begin{abstract}
Refractory black carbon aerosols (rBC) emitted by biomass burning (fires) and fossil fuel combustion, affect global climate and atmospheric chemistry. In the Southern Hemisphere $(\mathrm{SH}), \mathrm{rBC}$ is transported in the atmosphere from low- and mid-latitudes to Antarctica and deposited to the polar ice sheet preserving a history of emissions and atmospheric transport. Here, we present two high-resolution Antarctic rBC ice core records drilled from the West Antarctic Ice Sheet divide and Law Dome on the periphery of the East Antarctic ice sheet. Separated by $\sim 3500 \mathrm{~km}$, the records span calendar years 1850-2001 and reflect the rBC distribution over the Indian and Pacific ocean sectors of the Southern Ocean. Concentrations of rBC in the ice cores displayed significant variability at annual to decadal time scales, notably in ENSO-QBO and AAO frequency bands. The delay observed between $\mathrm{rBC}$ and ENSO variability suggested that ENSO does not directly affect rBC transport, but rather continental hydrology, subsequent fire regimes, and aerosol emissions. From 1850 to 1950 , the two ice core records were uncorrelated but were highly correlated from 1950 to 2002 (cross-correlation coefficient at annual resolution: $r=0.54$, $p<0.01)$ due to a common decrease in $\mathrm{rBC}$ variability. The decrease in ice-core rBC from the 1950 s to late 1980 s displays similarities with inventories of $\mathrm{SH}$ rBC grass fires and biofuel emissions, which show reduced emission estimates over that period.
\end{abstract}

\section{Introduction}

Refractory black carbon (rBC, soot) aerosols are present in the Antarctic atmosphere, snow and ice (Chýlek et al., 1987, 1992; Warren and Clarke, 1990; Grenfell et al., 1994). These aerosols are the result of long-range transport of biomass burning and fossil-fuel emissions across the Southern Ocean (Seiler and Crutzen, 1980; Crutzen and Andreae, 1990; Andreae et al., 2005). Ubiquitous in the troposphere, rBC aerosols are the primary absorber of visible light impacting the Earth's radiation budget and climate (Bond and Bergstrom, 2006). Recent estimates of the globally averaged radiative forcing for $\mathrm{rBC}$ are as high as $1.2 \mathrm{~W} \mathrm{~m}^{-2}$ (direct + indirect effects), making it the second highest radiative forcing after carbon dioxide (Ramanathan and Carmichael, 2008; Chung et al., 2005). However, the climate forcing from rBC in the atmosphere differs from that of greenhouse gases, which are well mixed and warm the Earth's surface. In contrast, $\mathrm{rBC}$ aerosols display large spatial and temporal gradients and heat the atmosphere while cooling the surface (Ramanathan and Carmichael, 2008). The highest atmospheric concentrations of $\mathrm{rBC}$ are found in the tropical belt due to the combustion of biomass and biofuels. These emissions are sensitive to changes in climate as well as to human activity such as tropical deforestation, land clearing, and fire suppression (Mouillot and Field, 2005). Although the effects of rBC

Published by Copernicus Publications on behalf of the European Geosciences Union. 
Table 1. Ranges and averages of annual rBC concentrations for this study and previous work in Greenland and Antarctica (snow and ice). Approximate location of WAIS and Law Dome sites are shown on the map on left hand corner.

\begin{tabular}{|c|c|c|c|c|c|c|c|c|c|}
\hline \multirow[b]{3}{*}{ WDC06A } & \multirow[b]{3}{*}{ 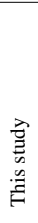 } & & \multirow[b]{2}{*}{ Location } & \multirow[b]{2}{*}{ Lat/long } & \multirow[b]{2}{*}{$\begin{array}{l}\text { Elevation } \\
\text { (a.s.l.) }\end{array}$} & \multirow[b]{2}{*}{$\begin{array}{l}\text { Age of sample (in } \\
\text { Cal. yr or as specified) }\end{array}$} & \multicolumn{2}{|c|}{ Annual concentrations $\left(\mu \mathrm{g} \mathrm{kg}^{-1}\right)$} & \multirow[b]{2}{*}{ Method } \\
\hline & & & & & & & Range $^{\mathrm{a}}$ & Mean and st deviation ${ }^{\mathrm{a}}$ & \\
\hline & & $\begin{array}{l}\text { Antarctica } \\
" \\
\text { Antarctica } \\
\#\end{array}$ & $\begin{array}{l}\text { WAIS (WDC06A) } \\
" \\
\text { Law Dome (DSSW19K) } \\
"\end{array}$ & $\begin{array}{l}79.46^{\circ} \mathrm{S}, 112.08^{\circ} \mathrm{W} \\
" \\
66.78^{\circ} \mathrm{S}, 112.37^{\circ} \mathrm{E} \\
"\end{array}$ & $\begin{array}{l}1766 \mathrm{~m} \\
, \\
1230 \mathrm{~m}^{\mathrm{b}} \\
,\end{array}$ & $\begin{array}{l}1970-2000 \\
1850-2000 \\
1970-2000 \\
1850-2000\end{array}$ & $\begin{array}{l}0.03 \text { to } 0.30 \\
0.03 \text { to } 0.30 \\
0.02 \text { to } 0.32 \\
0.01 \text { to } 0.55\end{array}$ & $\begin{array}{l}0.04<0.08<0.12 \\
0.05<0.08<0.12 \\
0.04<0.08<0.17 \\
0.05<0.09<0.20\end{array}$ & SP2-FIA \\
\hline Chylek et al. (1987) & & Antarctica & Siple Dome & $81.66^{\circ} \mathrm{S}, 148.83^{\circ} \mathrm{W}$ & $1050 \mathrm{~m}$ & recent snow & - & 2.5 & \\
\hline $\begin{array}{l}\text { Chylek et al. (1992) } \\
\text { " }\end{array}$ & & $\begin{array}{l}\text { Antarctica } \\
,\end{array}$ & Byrd station & $\begin{array}{l}80.02^{\circ} \mathrm{S}, 119.53^{\circ} \mathrm{W} \\
\end{array}$ & $1550 \mathrm{~m}$ & $\begin{array}{l}0.7 \text { to } 10 \mathrm{kyrBP} \\
10 \text { to } 14 \mathrm{kyrBP}\end{array}$ & $\begin{array}{l}0.1 \text { to } 0.95 \\
0.1 \text { to } 0.4\end{array}$ & $\begin{array}{l}0.5 \\
0.2\end{array}$ & Transmittance on \\
\hline $\begin{array}{l}\text { Warren and Clarke (1990) } \\
\text { Grenfell et al. (1994) } \\
\text { Grenfell et al. (1994) }\end{array}$ & & $\begin{array}{l}\text { Antarctica } \\
\text { Antarctica } \\
\text { Antarctica }\end{array}$ & $\begin{array}{l}\text { South Pole station } \\
\text { Vostok }\end{array}$ & $\begin{array}{l}90^{\circ} \mathrm{S}, 0^{\circ} \mathrm{W} \\
78.46^{\circ} \mathrm{S}, 106.83^{\circ} \mathrm{W}\end{array}$ & $\begin{array}{l}2830 \mathrm{~m} \\
= \\
3488 \mathrm{~m}\end{array}$ & $\begin{array}{l}\text { recent snow } \\
\text { recent snow } \\
\text { recent snow }\end{array}$ & $\begin{array}{l}0.1 \text { to } 0.3 \\
0.1 \text { to } 0.3 \\
1 \text { to } 7\end{array}$ & $\begin{array}{l}0.2 \\
0.3 \\
\text { (Contamination) }\end{array}$ & quartz fiber filter \\
\hline McConnell et al. (2007) & & Greenland & D4 & $71.4^{\circ} \mathrm{N}, 44.0^{\circ} \mathrm{W}$ & $2710 \mathrm{~m}$ & $1952-2002$ & $<1$ to 10 & 2.3 & SP2-FIA \\
\hline$"$ & & $"$ & $"$ & " & $"$ & $1851-1951$ & $\sim 1$ to 20 & 4 & \\
\hline $\begin{array}{l}\text { Chylek et al. (1995) } \\
\text { " }\end{array}$ & & $\begin{array}{l}\text { Greenland } \\
,\end{array}$ & $\begin{array}{l}\text { Summit/GISP2 } \\
\text { " }\end{array}$ & $72.36^{\circ} \mathrm{N}, 38.30^{\circ} \mathrm{W}$ & $\begin{array}{l}3200 \mathrm{~m} \\
, "\end{array}$ & $\begin{array}{l}320-330 \\
\text { recent snow }\end{array}$ & $\begin{array}{l}0.5 \text { to } 6.5 \\
-\end{array}$ & $\begin{array}{l}2.1 \\
2\end{array}$ & Transmittance on \\
\hline $\begin{array}{l}\text { Chylek et al. (1987) } \\
\text { ” }\end{array}$ & & Greenland & $\begin{array}{l}\text { Camp Century } \\
\text { „ }\end{array}$ & ${ }^{78.85^{\circ} \mathrm{N}, 55.232^{\circ} \mathrm{W}}$ & $2000 \mathrm{~m}$ & $\begin{array}{l}4 \text { kyrBP } \\
6 \mathrm{kyrBP}\end{array}$ & $\begin{array}{ll}- \\
-\end{array}$ & $\begin{array}{l}2.5 \\
1.1\end{array}$ & quartz fiber filter \\
\hline
\end{tabular}

${ }^{a}$ For this work only, annual concentrations are calculated from the log values of the monthly dataset. The mean value is thus the geometric mean of annual concentrations and standard deviations presented are geometric standard deviations. For Law Dome, outlier year 1910 has been excluded for range estimation.

b Altitude measured by Digital Elevation Model from Bamber et al. (2009).

in the modern atmosphere are numerous and well characterized, little is known regarding its past variability and sensitivity to climate change and human activity.

Ice core records preserve a history of $\mathrm{rBC}$ variability in the atmosphere with sufficient temporal-resolution to resolve seasonal changes in emission strength and atmospheric transport. Combined with general circulation modelling and $\mathrm{rBC}$ emission inventories, these records can provide constraints on the paleo-rBC atmospheric distribution, past biomass burning emissions and climate feedbacks (Lamarque et al., 2010; McConnell, 2010). High-temporal resolution ice core records of rBC from Greenland show that Northern Hemispheric rBC concentrations peaked during the early 20th Century due to fossil fuel combustion (McConnell et al., 2007; McConnell, 2010) and thus perturbed the Earth's radiation budget. In the Southern Hemisphere (SH), rBC emissions are primarily from dry-season biomass burning in Australia, southern Africa and South America (Mouillot and Field, 2005). Although a number of paleo-biomass burning records have shown centennial scale variability in biomass burning, high-temporal-resolution $\mathrm{rBC}$ records have not been reported (Marlon et al., 2008; Wang et al., 2010; Falk et al., 2010; Whitlock and Tinner, 2010). Here, we show two first high-resolution rBC records, from West and East Antarctica, covering the period 1850-2001, and investigate connections between $\mathrm{rBC}$ deposition, $\mathrm{SH}$ biomass burning and climate.

\section{Ice core locations and methods}

\subsection{Ice core sites}

Two high-temporal-resolution ice cores were studied and included the WDC06A core from West Antarctica (hereafter as the "WAIS core") and the DSSW19K core from Law Dome in East Antarctica (hereafter as the "Law Dome core"), Table 1 . The WAIS ice core $\left(79^{\circ} 46 \mathrm{~S} ; 112^{\circ} 08 \mathrm{~W}, 1766 \mathrm{~m}\right.$ a.s.l.) was drilled to a depth of $\sim 3330 \mathrm{~m}$ from 2007 to 2011 near the West Antarctic ice sheet divide (WAIS Divide, located $\sim 550 \mathrm{~km}$ inland). The record shown here covers the top $50.3 \mathrm{~m}$ of the ice core, which was drilled using an electromechanical drill in a dry bore. The Law Dome ice core site $\left(66^{\circ} 75 \mathrm{~S} ; 112^{\circ} 37 \mathrm{E}, 1230 \mathrm{~m}\right.$ a.s.l.) was located $19 \mathrm{~km}$ to the west of the Law Dome DSS ice core drill site $(4.7 \mathrm{~km} \mathrm{SSW}$ of summit, $\sim 100 \mathrm{~km}$ inland). The ice core was also drilled using an electromechanical drill in a dry bore, to a depth of $120 \mathrm{~m}$ in 2004 . This site is exposed primarily to an easterly maritime airflow from the Southern Ocean. The record shown here spans the top $37 \mathrm{~m}$ of the Law Dome ice core. Average ice-equivalent accumulation rates at the sites were similar: $\sim 20 \pm 3.4 \mathrm{~cm} \mathrm{a}^{-1}$ for WAIS (Banta et al., 2008), and $\sim 15 \pm 3.1 \mathrm{~cm} \mathrm{a}^{-1}$ for Law Dome. However, physical processes at Law Dome including the formation of sastrugi (dips and ridges formed by wind erosion) limit the temporal resolution at the site to $\sim 1 \mathrm{yr}$ while the WAIS record was found to preserve sub-annual variability (Banta et al., 2008).

\section{2 rBC ice core analysis}

Longitudinal sections of the WAIS and Law Dome ice cores were analysed for $\mathrm{rBC}$ using an ice-core melter system coupled to an ultrasonic nebulization/desolvation system (CETAC UT5000) (Bisiaux et al., 2011) and single particle intracavity laser induced incandescence photometer (SP2, Droplet Measurements Technologies, Boulder, Colorado). This analytical method is described by previous studies (McConnell et al., 2007) and is further described in supporting information. Using this method, $\mathrm{rBC}$ was determined in the 


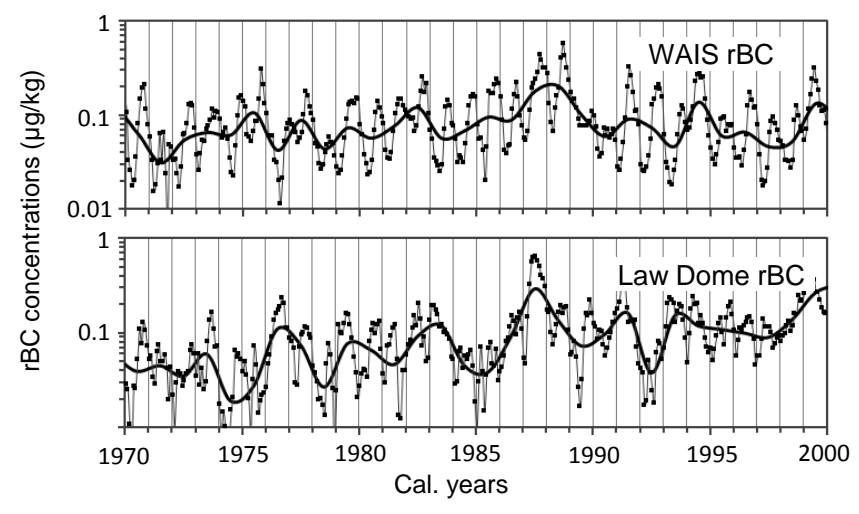

Fig. 1. 1970-2000 rBC concentrations in monthly resolution (dots and thin line) and resampled to annual (thick line) for WAIS and Law Dome records. Average analytical uncertainty on $\mathrm{rBC}$ measurement is $\sim 15 \%$.

ice core at a depth resolution of $\sim 1 \mathrm{~cm}$ corresponding to $\sim 25$ to 35 data points per year at WAIS and $\sim 10$ to 15 at Law Dome. Duplicate analysis revealed an average analytical uncertainty of $\sim 15 \%$.

\subsection{Dating}

Depth-age relationships for the records were developed using glaciochemistry and annual cycle counting for a suite of trace elements including sodium $(\mathrm{Na})$, chloride $(\mathrm{Cl})$, bromine $(\mathrm{Br})$ and sulphur $(\mathrm{S})$. Volcanic sulphur peaks associated with well documented eruptions (Tambora-1815, Krakatoa-1883, Agung-1963) were also used as absolute time markers to confirm the annual layer counting. Although annual cycles were extremely well preserved in the WAIS record, unambiguous sub-annual markers that could be tied to specific times of the year were not found for the Law Dome ice core. This is likely due to the local surface roughness height, which is close to the net snow accumulation rate at the site (Figs. 1 and S1). Instead, the depth-age relationship was validated using cross comparisons of continuous high resolution $\mathrm{S}, \mathrm{Na}$, and $\mathrm{Cl}$ measurements from a previous Law Dome ice core record (DSS0506). This DSS0506 core was drilled near the Law Dome summit (DSS) in 2005 in a higher snow accumulation zone and analysed in a similar fashion, but not for rBC. The record contained distinct annual cycles in many chemical species, and dating was unambiguous. Over the $150 \mathrm{yr}$ period investigated, we estimate the dating uncertainty to be $1 \mathrm{yr}$ for the Law Dome core and less than $1 \mathrm{yr}$ for the WAIS core.

\subsection{Fluxes}

While the dating uncertainty of the Law Dome record is greater than that of WAIS, it is sufficiently accurate to allow the calculation of net snow accumulation and rBC fluxes at both sites, especially when averaged over multi-annual to decadal time scales. Annual $\mathrm{rBC}$ flux rates were thus calculated by summing monthly flux rates, which were estimated by dividing the annual accumulation rate by 12 and multiplying by the monthly concentration.

\subsection{Data analysis}

Spectral analysis was used to investigate and extract the most prominent frequencies of $\mathrm{rBC}$ and $\mathrm{Na}$ concentration in the records. The analysis was performed using the multitaper method (Ghil et al., 2002), and the Blackman-Tukey method (coherence and phasing). Kspectra software (SpectraWorks) was used for the multitaper method and Analyseries (Paillard et al., 1996) for the Blackman-Tukey method. Spectral analysis, resampling (with piecewise linear-interpolation), and smoothing were conducted on the $\log$ of the original values and then back transformed to normal. For multitaper analysis, we used a dataset resampled to 12 values per year, which we termed "monthly" in the rest of the text. For coherence and phasing, we used a short period of $30 \mathrm{yr}$ for better readability of coherence. The period 1970-2001, was chosen because it was the most accurately dated and had the most distinct annual cycles. Datasets were resampled using a time resolution of $0.4 \mathrm{yr}$ in order to retain annual periodicity, remove any shorter-term variability, and increase readability. Phasing between the same periodicities was also determined through this method, and shown as a positive or negative value in radians as a function of the delay between the two series. Smoothing was estimated with an $\mathrm{R}$ implementation of Nadaraya-Watson kernel regression for a period of $21 \mathrm{yr}$, which is long enough to be repeated at least five times in the $150 \mathrm{yr}$ period, while still capturing the primary variability in the top part of the record.

\section{Results and discussion}

\subsection{Concentrations and fluxes}

Concentrations of $\mathrm{rBC}$ in both records were log-normally distributed (Fig. S2) with geometric means of $0.08 \mu \mathrm{g} \mathrm{kg}^{-1}$ $(n=4860)$ and $0.09 \mathrm{\mu g} \mathrm{kg}^{-1}(n=2883)$ for WAIS and Law Dome, respectively, Table 1. In the WAIS core, sub-annual rBC concentrations were highly seasonal (Fig. 1), with consistent low austral summer/fall concentrations averaging $0.04 \mu \mathrm{g} \mathrm{kg}^{-1}$ and high winter/spring concentrations averaging $0.15 \mu \mathrm{g} \mathrm{kg}^{-1}$. The seasonal variability (summer/fall and winter/spring) of $\mathrm{rBC}$ concentrations at Law Dome was less than at WAIS, with an average intra-annual range of $0.08 \mu \mathrm{g} \mathrm{kg}^{-1}$ at Law Dome and $0.12 \mu \mathrm{g} \mathrm{kg}^{-1}$ at WAIS. In contrast, year-to-year variability of annual averaged (geometric) concentrations was greater for Law Dome than WAIS, despite a comparable annual geometric mean of $\sim 0.08 \mathrm{\mu g} \mathrm{kg}^{-1}$ for the entire record (Table 1). Concentrations determined in the records were comparable to the snow rBC concentrations reported by Warren and Clarke (1990) 


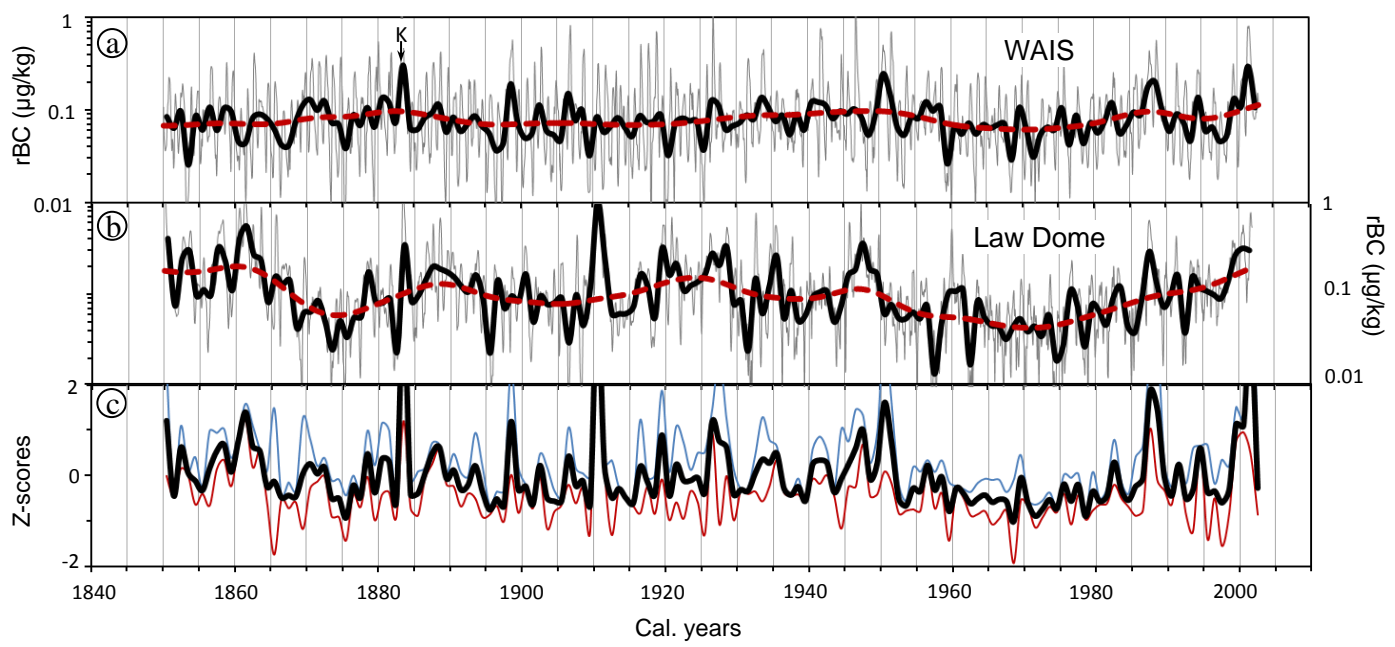

Fig. 2. $\mathrm{rBC}$ concentrations in monthly resolution (thin line), and resampled to annual (thick line) for WAIS (a) and Law Dome (b). Red dash line is $21 \mathrm{yr}$ smoothing. $\mathrm{K}$ marks the Krakatoa volcanic eruption used for dating. Average analytical uncertainty on rBC measurement is $\sim 15 \%$. Panel (c) shows a single rBC record reconstructed from the two sites: the two records were converted to Z-scores and stacked together (black line). High values represent high $\mathrm{rBC}$ concentrations. The blue and red lines are the standard error of the two records.

and Grenfell et al. (1994), and similar to those derived from a GCM model (Flanner et al., 2007), but were lower than concentrations measured in older Antarctic ice by Chýlek et al. (1992), Table 1. Differences in the reported concentration range likely reflect the different time periods encompassed by the measurement and spatial variability, as well as the analytical methods used (Bisiaux et al., 2011; Kaspari et al., 2011). Annual rBC fluxes, estimated from rBC concentrations and annual accumulation rate estimates were $16 \pm 2.7 \mu \mathrm{g} \mathrm{m}^{-2} \mathrm{a}^{-1}$ at WAIS and $13.5 \pm 2.7 \mu \mathrm{g} \mathrm{m}^{-2} \mathrm{a}^{-1}$ at Law Dome for the same time period.

\subsection{Temporal variability: comparison with sodium records}

Time series of rBC concentrations from 1850 to 2000 are shown in Fig. 2. Figure 2c shows the single stacked rBC record reconstructed from Z-scores of WAIS and Law Dome ice core records. Both sites displayed significant annual to decadal scale variability prior to 1950 , and common variability with low standard error from 1950 onwards. After 1950 rBC concentrations decreased until $\sim 1975$ and then rose to pre-1950 concentrations (cross correlation coefficient for annual data: $r=0.54, p<0.01$; for monthly data: $r=0.20, p<0.01)$. The decline in $\mathrm{rBC}$ at WAIS during this period was not related to changes in the snow accumulation rate, which was extremely stable during this time (Banta et al., 2008). At Law Dome, changes in the accumulation rate have been found for the DSS ice core site (van Ommen and Morgan, 2010), located 19km from the site presented here (DSSW19K). This is known to be a regionally coherent change with other records on Law Dome and in Eastern Wilkes Land showing similar patterns (Morgan et al., 1991). The DSS record shows an unusual increase in snow accumulation after 1975 associated with changes in zonal atmospheric circulation. However, no significant correlation was found between the DSS snow accumulation record and DSSW19K $\mathrm{rBC}$ record $\left(R^{2}=0.07, p=0.41\right.$ for annual records and $R^{2}=-0.14, p=0.08$ for $5 \mathrm{yr}$ smoothed records).

Ultimately variability in the ice core records reflects variability in rBC emissions, atmospheric transport, and deposition during transport and physical processes at the ice core site. Stohl and Soderman (2010) developed a 5.5-yr climatology (1999 to 2005) for atmospheric transport into the Antarctic troposphere using a Lagrangian particle dispersion model (FLEXPART). The study used rBC emissions described in Bond et al. (2007) and Schultz et al. (2008) and did not include depositional processes. The results suggest that $\mathrm{rBC}$ in the Antarctic troposphere is most sensitive to fire emissions from Australian and South American during the austral winter/spring, as well as anthropogenic emissions from South American. Southern Africa, which has the largest rBC emissions, had the least potential to influence Antarctic rBC. This confirmed findings by Li et al. (2008), who argued for stronger dust supply to Antarctica from Australia and South America, than from South Africa. De Dekker et al. (2010) investigated dust transport from Australia using the NOAA Hybrid Single-Particle Lagrangian Integrated Trajectory model (HYSPLIT, R. R. Draxler and G. D. Rolph, Hybrid SingleParticle Lagrangian Integrated Trajectory model, 2003). The back trajectory analysis showed that aerosols (rBC and dust), from central Australia may perturb the aerosol mass loading over West Antarctica. We speculate that enhanced meridional transport of African $\mathrm{rBC}$ prior to the 1950s may account for 


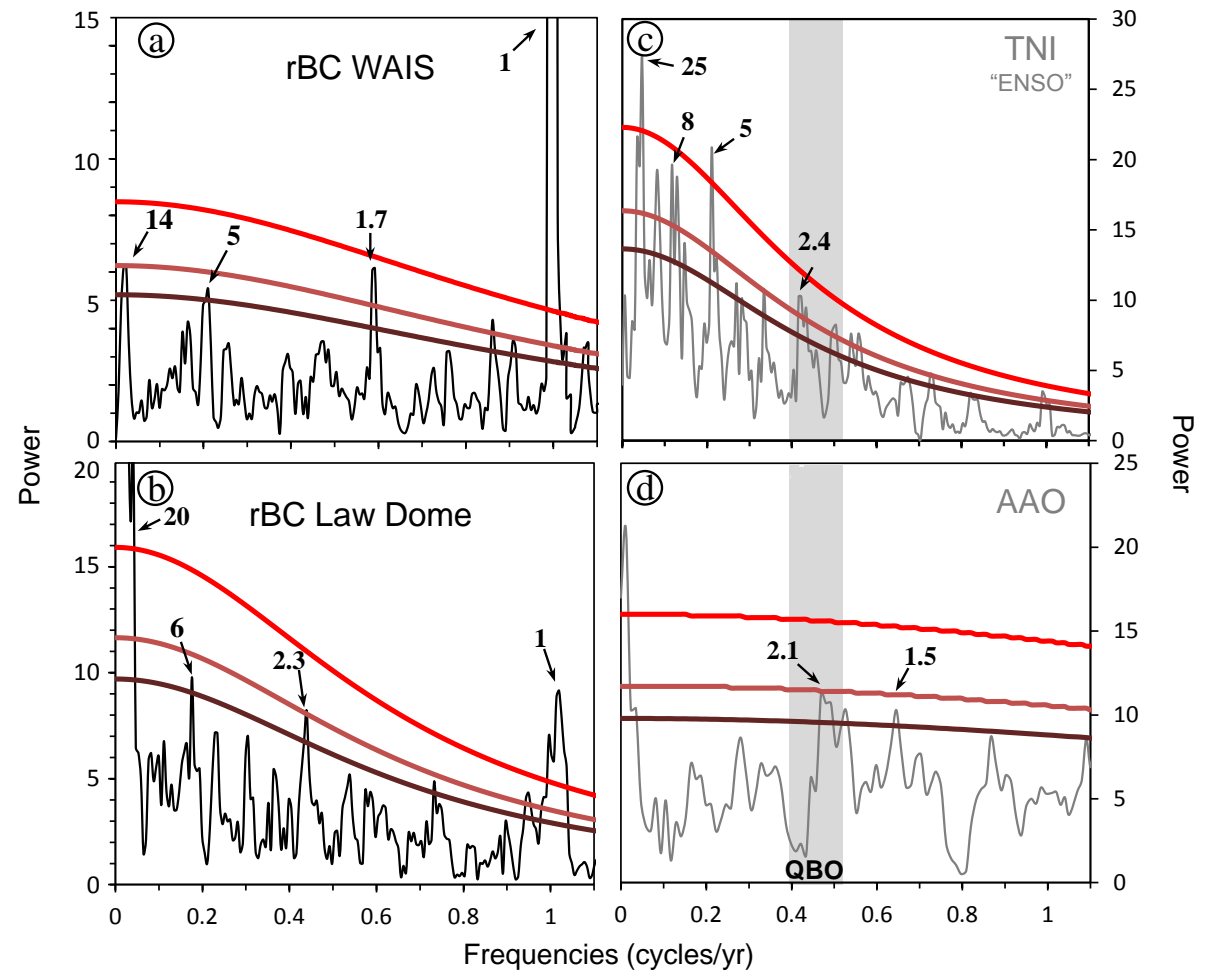

Fig. 3. Spectra obtained by multitaper method, for WAIS (a) and Law Dome (b) monthly rBC records for 1850-2001 period. For reference, spectra for ENSO (c) and AAO (d) are also represented. The QBO band (2.3-2.6 yr band) is indicated as a shaded area. Confidence levels (AR1) are indicated as red lines $(90,95,99 \%)$. Significant periodicities are indicated with an arrow and corresponding values in years are noted. For ENSO, we used the monthly Southern Oscillation Index from 1877 to 2002 from the Bureau of Meteorology, National Climate Centre Climate Analysis Section downloaded at http://www.bom.gov.au/climate/current/soihtm1.shtml. For AAO, we used the BAS NERC dataset from 1957 to 2007 downloaded at http://www.nerc-bas.ac.uk/public/icd/gjma/newsam.1957.2007.txt. For QBO, we used the NOAA/ESRL PSD dataset from 1948 to 2011 (30 mb zonal wind at the equator, zonal average), downloaded at http://www.esrl.noaa.gov/ $\mathrm{psd} / \mathrm{data} /$ correlation/qbo.data on January 2012.

the lack of correlation between the records, but more atmospheric general circulation modelling studies are needed to support this idea. To investigate the effect of local to regional changes in atmospheric circulation on the $\mathrm{rBC}$ records, the time series were compared with co-registered records of sodium ( $\mathrm{Na}$. $\mathrm{Na}$ is a sea-salt proxy modulated by atmospheric transport as well as the seasonal variability of salt emissions from the Southern Ocean and to a lesser extent from the surface of sea ice (Legrand and Mayewski, 1997; Curran et al., 1998; Goodwin et al., 2004). Na displays a strong seasonality and is primarily delivered to the Antarctic winter/spring (Sneed et al., 2011). The records of $\mathrm{rBC}$ and $\mathrm{Na}$ at Law Dome and WAIS were found to be autocorrelated due to the presence of an annual cycle in both species. However, phase analysis between $\mathrm{Na}$ annual maximum and $\mathrm{rBC}$ annual maximum revealed a difference of $\sim 3$ months at WAIS and $\sim 2$ months at Law Dome, with $\mathrm{Na}$ leading $\mathrm{rBC}$ (Fig. S3). This suggests that $\mathrm{rBC}$ variability is not sensitive to atmospheric transport associated with cyclonic systems in the Southern Ocean, which is the principal source of $\mathrm{Na}$ in the ice core (Sneed et al., 2011). Variabil- ity of source emissions and meridional atmospheric transport (hemispheric) from low-mid latitudes is thus assumed to be the primary factors affecting $\mathrm{rBC}$ variability in the records.

\subsection{Relationships between rBC emissions and ENSO}

Spectral analysis of the rBC records over the 1850 to 2001 period revealed significant periodicities in the $5 \mathrm{yr}$ band at WAIS (AR1 $\mathrm{CI}=90 \%$ ) and $6 \mathrm{yr}$ band at Law Dome (AR1 $\mathrm{CI}=95 \%$ ), Fig. 3a, b. This suggests that El Niño Southern Oscillation (ENSO) related climate variability may be responsible for some of the intra-annual variability in the records ( $\mathrm{Li}$ et al., 2011), Fig. 3c. Moreover, the two rBC records were found to be coherent in the ENSO band (average coherence coefficient $>0.38$ for 1970-2001 period, Fig. S5a) confirming a common modulation by ENSO. No ENSO periodicities were found in the WAIS $\mathrm{Na}$ record (Fig. S3a), suggesting that the ENSO signal found in the WAIS $\mathrm{rBC}$ record is likely to be linked to source emission variability rather than transport. 
On the contrary, significant ENSO and AAO periodicities (AR1, $>95 \%$ ) were found in the Na record from Law Dome (Fig. S3b), which suggests that ENSO and AAO affect atmospheric transport of sea salt to Law Dome. Goodwin et al. (2004) also report ENSO and AAO related variability in the Law Dome Na record over the past 700 yr. The study found that early winter Na concentrations (May to July) were highly correlated with mean sea level pressure (MSLP) in the South Indian and southwest Pacific Oceans, and southern Australian regions. Furthermore, Na was found to be anti-correlated with AAO variability and associated with enhanced meridional atmospheric transport. Compared to the Law Dome Na record, the rBC-ENSO periodicities were found to be systematically delayed by 0.3 to $2.2 \mathrm{yr}$ (Fig. S4d). The delay suggests that at Law Dome, ENSO influences the $\mathrm{rBC}$ record differently than the Na record. This is coherent with the current understanding of fire occurrence in response to changes in rainfall, which is also modulated by ENSO (Chen et al., 2011). For instance, an El Niño event may induce exceptional moisture in South America and prevent fires from occurring in forests. On the contrary, an increase in rainfall during La Niña may accelerate vegetation growth in Australian savannahs and thereby increase fire emissions for several years after the La Niña (Krawchuk and Moritz, 2011). Thus, the link between rBC emissions and ENSO may be related to changes in $\mathrm{SH}$ rainfall rather than atmospheric transport. This may explain the delay found between the Law Dome ENSO rBC and Na.

Other significant periodicities were found in the $\mathrm{rBC}$ records. At Law Dome, a 2.3 yr oscillation (AR1 CI =95\%) may correspond to the Quasi-biennial Oscillation band (QBO, Fig. 3a, c, d). Since this periodicity was not observed in the Na record, we suggest that the QBO is likely to affect $\mathrm{rBC}$ emissions in a similar fashion as ENSO through hydroclimate modification (Baldwin et al., 2001). At WAIS, a $1.7 \mathrm{yr}$ periodicity in the $\mathrm{rBC}$ record (AR1 CI $=99 \%$, Fig. 3a) and in the $\mathrm{Na}$ record (AR1 CI $=90 \%$, Fig. S3a), may be associated with the Antarctic Oscillation (AAO, Fig. 3d). This relationship may reflect an influence from atmospheric transport in the mid to high-southern latitudes (Gong and Wang, 1999).

\subsection{Decadal scale variability and comparison with SH rBC emission inventories}

On the decadal scale, the rBC records show similar features and variability, which appear to have no analogue in the ice core Na records or climatic indexes such as ENSO and the Southern Annular Mode (SAM). Notably, beginning in the late 1950s and lasting until $\sim 1985$, rBC concentrations decreased abruptly (Figs. 2 and 4) and in parallel with the start of a low-variance period that is common to the two records (Fig. S6). This period of decreased concentration and variance is consistent with rBC emissions inventories (Fig. 4) from Australian and South American grass fires (Lamarque

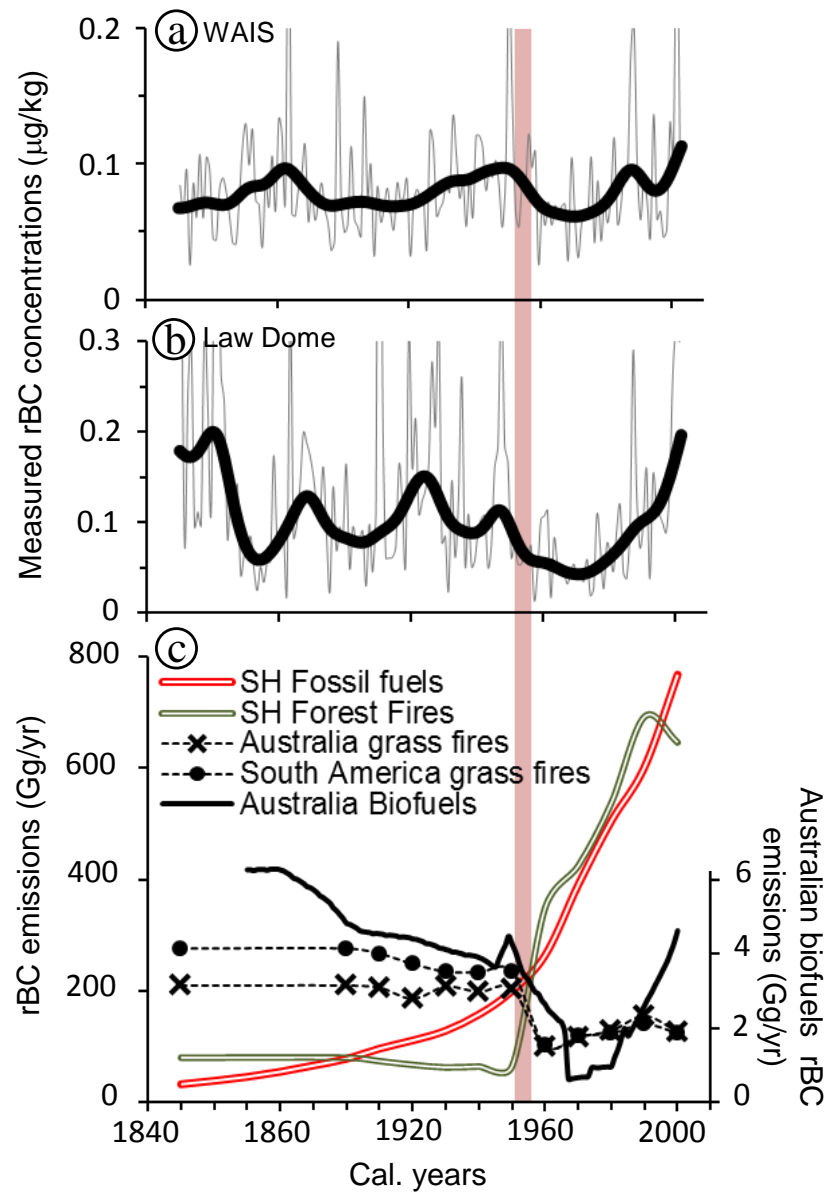

Fig. 4. (a, b) rBC records for WAIS and Law Dome. In gray, concentrations re-sampled to annual resolution. Dark thick lines are 21 yr smoothing. (c) Comparison with reconstructed $\mathrm{rBC}$ emissions from $\mathrm{SH}$ fossil fuel anthropogenic use, $\mathrm{SH}$ forest fires, Australian grass fires, South American grass fires (Lamarque et al., 2010) left scale - and from Australian biofuels (Ito and Penner, 2005) right scale. The vertical bar highlights the beginning of fire prevention in Australia.

et al., 2010) and Australia biofuel emissions (Ito and Penner, 2005). This period also coincides with the start of Australian rational fire prevention policies (prescribed fires instead of total fire suppression), which began in the 1950s (Mouillot and Field, 2005). Similar temporal variability does not occur in the emission inventory for SH forest fires, which show an increasing trend from the 1950s (Mouillot and Field, 2005). However, we note that recent estimates of SH rBC emissions (GFED 3, van der Werf et al., 2010) attribute 41\% of SH rBC to grass fires (61\% if woodlands are included), $\sim 9 \%$ from forest fires, and $26 \%$ from deforestation (primarily in South America). Thus, changes in the SH grassland (and woodland) fire regime from human activity and climate (hydroclimate) could dominate the $\mathrm{SH} \mathrm{rBC}$ distribution. The marked increase in $\mathrm{SH}$ rBC emissions from human activity 
since 1950, including fossil fuel consumption and deforestation (which doubled in the Amazon basin between 1960 to 1975-1980) (Mouillot and Field, 2005), in addition to increase fossil fuel consumption after 1950 (Ito and Penner, 2005; Lamarque et al., 2010), Fig. 4, may be reflected in increasing $\mathrm{rBC}$ concentrations observed in the last decades of the WAIS and Law Dome ice cores records.

During the earlier period (1850-1950), the two series do not share the same variability, and little evidence of anthropogenic changes in $\mathrm{SH}$ rBC emissions has been documented (Mouillot and Field, 2005; Lamarque et al., 2010). However, coal mining and burning was already established at the end of the 19th century in Australia, South America and South Africa (Vallelonga et al., 2002 and references therein), along with human settlement, and may have contributed to a small extent to $\mathrm{rBC}$ deposition to Antarctica. We thus suggest that the $\mathrm{rBC}$ signal for this period is primarily influenced by climate variability but longer records are needed to quantify natural $\mathrm{rBC}$ variability to these regions of Antarctica.

\section{Conclusions}

Ice core records of $\mathrm{rBC}$ from West and East Antarctica show changes is $\mathrm{rBC}$ concentrations and fluxes over the past $150 \mathrm{yr}$. These records are the first of their kind in Antarctica and represent a link between polar ice core records and low-mid latitude fires. The records appear to be influenced by variability similar to tropical Pacific climatic variability (ENSO) possibly due to the lagged response of grassland fuel loading to hydroclimate variability. Common variability in the records from the 1950s to 1980s was also coincident with decadal variability in grassland and biofuel $\mathrm{rBC}$ emission inventories (Ito and Penner, 2005; Lamarque et al., 2010). Thus, the records may be influenced by both climate variability and human activity. Further research combining general circulation model based $\mathrm{rBC}$ simulations with improved geospatial estimates of $\mathrm{rBC}$ emissions are required to deconvolve these factors. New ice core records are also required to investigate the spatial variability of $\mathrm{rBC}$ transport and deposition to Antarctica. In particular, development of ice core $\mathrm{rBC}$ records from Antarctic regions exposed to Atlantic air masses are needed to reconcile the temporal variability found in this study with increased emissions from South American deforestation and fossil-fuel combustion.

\section{Supplementary material related to this article is available online at: http://www.atmos-chem-phys.net/12/ 4107/2012/acp-12-4107-2012-supplement.pdf.}

Acknowledgements. This work was supported by NSF grants OPP 0739780, 0839496, 0538416, 0538427, the Australian Government's Cooperative Research Centres Programme through the
Antarctic Climate and Ecosystems Cooperative Research Centre (ACE CRC) and the Desert Research Institute. We gratefully acknowledge the WAIS divide drilling team, the Law Dome drilling team and the DRI ice core team. The authors appreciate the support of the WAIS Divide Science Coordination Office at the Desert Research Institute of Reno Nevada for the collection and distribution of the WAIS Divide ice core and related tasks (NSF Grants 0440817 and 0230396). The NSF Office of Polar Programs also funds the Ice Drilling Program Office and Ice Drilling Design and Operations group for coring activities; Raytheon Polar Services for logistics support in Antarctica; and the 109th New York Air National Guard for airlift in Antarctica. The National Ice Core Laboratory, which archived the WAIS core and preformed core processing, is funded by the National Science Foundation. We thank Jean-Robert Petit for help and advice on spectral analysis as well as Jean-Francois Lamarque and Ito Akinory for help with emissions inventories.

Edited by: Y. Balkanski

\section{References}

Andreae, M. O., Jones, C. D., and Cox, P. M.: Strong present-day aerosol cooling implies a hot future, Nature, 435, 1187-1190, 2005.

Baldwin, M. P., Gray, L. J., Dunkerton, T. J., Hamilton, K., Haynes, P. H., Randel, W. J., Holton, J. R., Alexander, M. J., Hirota, I., Horinouchi, T., Jones, D. B. A., Kinnersley, J. S., Marquardt, C., Sato, K., and Takahashi, M.: The quasi-biennial oscillation, Rev. Geophys., 39, 179-229, doi:10.1029/1999rg000073, 2001.

Bamber, J. L., Gomez-Dans, J. L., and Griggs, J. A.: Antarctic 1 km Digital Elevation Model (DEM) from Combined ERS-1 Radar and ICESat Laser Satellite Altimetry, Boulder, Colorado USA, National Snow and Ice Data Center, Digital Media, 2009.

Banta, J. R., McConnell, J. R., Frey, M. M., Bales, R. C., and Taylor, K.: Spatial and temporal variability in snow accumulation at the West Antarctic Ice Sheet Divide over recent centuries, J. Geophys. Res., 113, D23102, doi:10.1029/2008jd010235, 2008.

Bisiaux, M. M., Edwards, R., Heyvaert, A. C., Thomas, J. M., Fitzgerald, B., Susfalk, R. B., Schladow, S. G., and Thaw, M.: Stormwater and fire as sources of black carbon nanoparticles to Lake Tahoe, Environ. Sci. Technol., 45, 2065-2071, doi:10.1021/es103819v, 2011.

Bond, T. C. and Bergstrom, R. W.: Light Absorption by Carbonaceous Particles: An Investigative Review, Aerosol Sci. Technol., 40, 27-67, 2006.

Bond, T. C., Bhardwaj, E., Dong, R., Jogani, R., Jung, S., Roden, C., Streets, D. G., and Trautmann, N. M.: Historical emissions of black and organic carbon aerosol from energyrelated combustion, Global Biogeochem. Cy., 21, GB2018, doi:10.1029/2006gb002840, 2007.

Chen, Y., Randerson, J. T., Morton, D. C., DeFries, R. S., Collatz, G. J., Kasibhatla, P. S., Giglio, L., Jin, Y., and Marlier, M. E.: Forecasting Fire Season Severity in South America Using Sea Surface Temperature Anomalies, Science, 334, 787-791, doi:10.1126/science.1209472, 2011.

Chung, C. E., Ramanathan, V., Kim, D., and Podgorny, I. A.: Global anthropogenic aerosol direct forcing derived from satellite and 
ground-based observations, J. Geophys. Res., 110, D24207, doi:10.1029/2005jd006356, 2005.

Chýlek, P., Srivastava, V., Cahenzli, L., Pinnick, R. G., Dod, R. L., Novakov, T., Cook, T. L., and Hinds, B. D.: Aerosol and Graphitic Carbon Content of Snow, J. Geophys. Res., 92, 98019809, doi:10.1029/JD092iD08p09801, 1987.

Chýlek, P., Johnson, B., and Wu, H.: Black carbon concentration in Byrd station ice core - From 13,000 to 700 years before present, Ann. Geophys., 10, 625-629, 1992,

http://www.ann-geophys.net/10/625/1992/.

Crutzen, P. J. and Andreae, M. O.: Biomass burning in the tropics: Impact on atmospheric chemistry and biogeochemical cycles, Science, 250, 1669-1678, doi:10.1126/science.250.4988.1669, 1990.

Curran, M. A. J., van Ommen, T. D., and Morgan, V.: Seasonal characteristics of the major ions in the high accumulation DSS ice core, Law Dome, Antarctica, Ann. Glaciol., 22, 83-794, doi:10.1007/s00382-004-0403-3, 1998.

De Deckker, P., Norman, M., Goodwin, I. D., Wain, A., and Gingele, F. X.: Lead isotopic evidence for an Australian source of aeolian dust to Antarctica at times over the last 170,000 years, Palaeogeogr. Palaeocl., 285, 205-223, 2010.

Falk, D. A., Heyerdahl, E. K., Brown, P. M., Swetnam, T. W., Sutherland, E. K., Gedalof, Z., Yocom, L., and Brown, T. J.: Fire and climate variation in western North America from fire-scar and tree-ring networks, PAGES news, 18, 70-72, 2010.

Flanner, M. G., Zender, C. S., Randerson, J. T., and Rasch, P. J.: Present-day climate forcing and response from black carbon in snow, J. Geophys. Res.-Atmos., 112, D11202, doi:10.1029/2006jd008003, 2007.

Ghil, M., Allen, M. R., Dettinger, M. D., Ide, K., Kondrashov, D., Mann, M. E., Robertson, A. W., Saunders, A., Tian, Y., Varadi, F., and Yiou, P.: Advanced spectral methods for climatic time series, Rev. Geophys., 40, 1003, doi:10.1029/2000rg000092, 2002.

Gong, D. and Wang, S.: Definition of Antarctic Oscillation index, Geophys. Res. Lett., 26, 459-462, doi:10.1029/1999gl900003, 1999.

Goodwin, I. D., van Ommen, T. D., Curran, M. A. J., and Mayewski, P. A.: Mid latitude winter climate variability in the South Indian and southwest Pacific regions since 1300 AD, Clim. Dynam., 22, 783-794, doi:10.1007/s00382-004-0403-3, 2004.

Grenfell, T. C., Warren, S. G., and Mullen, P. C.: Reflection of solarradiation by the Antarctic snow surface at ultraviolet, visible, and near-infrared wavelenghts, J. Geophys. Res.-Atmos., 99, 1866918684, 1994.

Ito, A. and Penner, J. E.: Historical emissions of carbonaceous aerosols from biomass and fossil fuel burning for the period 1870-2000, Global Biogeochem. Cy., 19, GB2028, doi:10.1029/2004gb002374, 2005.

Kaspari, S. D., Schwikowski, M., Gysel, M., Flanner, M. G., Kang, S., Hou, S., and Mayewski, P. A.: Recent increase in black carbon concentrations from a Mt. Everest ice core spanning 1860-2000 AD, Geophys. Res. Lett., 38, L04703, doi:10.1029/2010g1046096, 2011.

Krawchuk, M. A. and Moritz, M. A.: Constraints on global fire activity vary across a resource gradient, Ecology, 92, 121-132, doi:10.1890/09-1843.1, 2011.

Lamarque, J.-F., Bond, T. C., Eyring, V., Granier, C., Heil, A., Klimont, Z., Lee, D., Liousse, C., Mieville, A., Owen, B.,
Schultz, M. G., Shindell, D., Smith, S. J., Stehfest, E., Van Aardenne, J., Cooper, O. R., Kainuma, M., Mahowald, N., McConnell, J. R., Naik, V., Riahi, K., and van Vuuren, D. P.: Historical (1850-2000) gridded anthropogenic and biomass burning emissions of reactive gases and aerosols: methodology and application, Atmos. Chem. Phys., 10, 7017-7039, doi:10.5194/acp10-7017-2010, 2010.

Legrand, M. and Mayewski, P.: Glaciochemistry of polar ice cores: A review, Rev. Geophys., 35, 219-243, doi:10.1029/96rg03527, 1997.

Li, F., Ginoux, P., and Ramaswamy, V.: Distribution, transport, and deposition of mineral dust in the Southern Ocean and Antarctica: Contribution of major sources, J. Geophys. Res., 113, D10207, doi:10.1029/2007jd009190, 2008.

Li, J., Xie, S.-P., Cook, E. R., Huang, G., D’Arrigo, R., Liu, F., Ma, J., and Zheng, X.-T.: Interdecadal modulation of El Nino amplitude during the past millennium, Nature Climate Change, 1, 114-118, 2011.

Marlon, J. R., Bartlein, P. J., Carcaillet, C., Gavin, D. G., Harrison, S. P., Higuera, P. E., Joos, F., Power, M. J., and Prentice, I. C.: Climate and human influences on global biomass burning over the past two millennia, Nat. Geosci., 1, 697-702, doi:10.1038/ngeo313, 2008.

McConnell, J. R.: New Directions: Historical black carbon and other ice core aerosol records in the Arctic for GCM evaluation, Atmos. Environ., 44, 2665-2666, 2010.

McConnell, J. R., Edwards, R., Kok, G. L., Flanner, M. G., Zender, C. S., Saltzman, E. S., Banta, J. R., Pasteris, D. R., Carter, M. M., and Kahl, J. D. W.: 20th-century industrial black carbon emissions altered arctic climate forcing, Science, 317, 1381-1384, doi:10.1126/science.1144856, 2007.

Morgan, V. I., Goodwin, I. D., Etheridget, D. M., and Wookey, C. W.: Evidence from Antarctic ice cores for recent increases in snow accumulation, Nature, 354, 58-60, 1991.

Mouillot, F. and Field, C. B.: Fire history and the global carbon budget: a $1^{\circ} \times 1^{\circ}$ fire history reconstruction for the 20th century, Glob. Change Biol., 11, 398-420, doi:10.1111/j.13652486.2005.00920.x, 2005.

Paillard, D., Labeyrie, L., and Yiou, P.: Macintosh program performs time-series analysis, Eos Trans. AGU, 77, p. 379, 1996.

Ramanathan, V. and Carmichael, G.: Global and regional climate changes due to black carbon, Nat. Geosci., 1, 221-227, doi:10.1038/ngeo156, 2008.

Schultz, M. G., Heil, A., Hoelzemann, J. J., Spessa, A., Thonicke, K., Goldammer, J. G., Held, A. C., Pereira, J. M. C., and van het Bolscher, M.: Global wildland fire emissions from 1960 to 2000, Global Biogeochem. Cy., 22, GB2002, doi:10.1029/2007gb003031, 2008.

Seiler, W. and Crutzen, P. J.: Estimates of gross and net fluxes of carbon between the biosphere and the atmosphere from biomass burning, Clim. Change, 2, 207-247, 1980

Sneed, S. B., Mayewski, P. A., and Dixon, D. A.: An emerging technique: multi-ice-core multi-parameter correlations with Antarctic sea-ice extent, Ann. Glaciol., 52, 347-354, 2011.

Stohl, A. and Sodemann, H.: Characteristics of atmospheric transport into the Antarctic troposphere, J. Geophys. Res., 115, D02305, doi:10.1029/2009jd012536, 2010.

Vallelonga, P., Van de Velde, K., Candelone, J. P., Morgan, V. I., Boutron, C. F., and Rosman, K. J. R.: The lead pollution history 
of Law Dome, Antarctica, from isotopic measurements on ice cores: 1500 AD to 1989 AD, Earth Planet. Sc. Lett., 204, 291306, 2002.

van der Werf, G. R., Randerson, J. T., Giglio, L., Collatz, G. J., Mu, M., Kasibhatla, P. S., Morton, D. C., DeFries, R. S., Jin, Y., and van Leeuwen, T. T.: Global fire emissions and the contribution of deforestation, savanna, forest, agricultural, and peat fires (19972009), Atmos. Chem. Phys., 10, 11707-11735, doi:10.5194/acp10-11707-2010, 2010.

van Ommen, T. D. and Morgan, V.: Snowfall increase in coastal East Antarctica linked with southwest Western Australian drought, Nat. Geosci., 3, 267-272, 2010.
Wang, Z., Chappellaz, J., Park, K., and Mak, J. E.: Large Variations in Southern Hemisphere Biomass Burning During the Last 650 Years, Science, 330, 1663-1666, doi:10.1126/science.1197257, 2010.

Warren, S. G. and Clarke, A. D.: Soot in the atmosphere and snow surface of Antarctica, J. Geophys. Res.-Atmos., 95, 1811-1816, 1990.

Whitlock, C. and Tinner, W.: Editorial: Fire in the Earth System, Pages news, 18, 55-56, 2010. 